\section{ATOMIC ENERGY}

\section{Construction Costs Sour}

The Central Electricity Generating Board has adopted. a new strategy for the construction of its latest nuclear power station, Sizewell "B", by splitting up the contract so that the nuclear components will be tendered for separately from the generators and the civil engineering work. 'This practice of splitting up contracts has been common for conventional stations, but has never been applied to nuclear plant.

The CEGB has awarded the design contract for the 2,500 MW Sizewell B station to the Nuclear Power Group, one of the two British design and construction consortia, and it seems certain that the NPG will be given a firm contract next year for the construction of the nuclear islands, estimated to be worth about $£ 140$ million.

Sizewell B will be the largest nuclear power station in Britain when the last of its four reactors goes critical in 1977. The total cost is expected to be about $£ 250$ million. which marks a considerable increase in capital cost per kilowatt since the Hinkley Point $B$ station, also an advanced gas cooled reactor system, was started in 1967. Hinkley Point $B$ cost about $£ 76$ a kilowatt whereas expenditure on Sizewell B is expected to reach about $£ 100$ a kilowatt. The CEGB points out, however, that the costs have still to be finalized.

\section{UNIVERSITIES}

\section{Selection Procedures Condemned}

A stinging attack on the system of entry to British universities was delivered last week by the National Association of Careers Teachers. In a letter sent to the Committee of Vice-chancellors and to other bodies responsible for university admissions, the association points to many faults in the workings of the Universities Central Council on Admissions, and it is particularly scathing about the lack of liaison between universities and schools. There is rivalry between universities, faculties and departments, the association suggests, "and in consequence heads and careers teachers receive little help from these sources which may be used as a basis for reports on applicants from their schools".

The accusations are based on a recent survey of university applications carried out by the association. The letter points out, for example, that the apparent choice of five universities offered by the UCCA is a choice "on paper only". "It is patently obvious," says the association, "that for popular courses such as law, medicine and languages, those universities placed fourth and fifth rarely give serious consideration if any at all to the applicants concerned".

What is to be done? The association suggests that one of the more obvious drawbacks in the present selection system is that the universities select students before their A-level results are announced, and this results in undue complication. There is therefore a good case for reviewing the whole system of university selection, adjusting examination times so that the results are published by the end of July and moving the start of the first year of university courses to November. Alternatively, the association suggests, a student could be compelled to break off his studies for one year between A levels and university.

\section{Parliament in Britain}

Transfer of Research Establishments

RESPONSIBILITY for the Water Pollution Research Laboratory, the Hydraulic Research Station, the Forest Products Research Station and the Fire Research Station will be transferred from the Department of Trade and Industry to the Department for the Environment on January 1, 1971. Announcing this transfer, Mr David Howell, Parliamentary Secretary to the Civil Service Department, said that the functions of these laboratories fall chiefly within the ambit of the now Department for the Environment. By the same token, the Department for the Environment will take over the responsibility for administering grants to the Water Research Association and to the Construction Industry Research and Information Association. All these responsibilities were previously assumed by the Ministry of 'Technology. (Writtenanswers, November 10.)

\section{Research and Development Estimates}

THE government intends to spend about $£ 63$ million on research and development in its own establishments in 1970-71. This figure includes expenditure on the Atomic Energy Authority, and it is about the same as the estimated total expenditure in 1968-69 and 1969-70. This announcement was made by $\mathrm{Mr}$ Nicholas Ridley, Under Secretary of State, Department of Trade and Industry, in reply to a question from Mr J. H. Osborn. (Written answers, November 9.)

\section{British Steel Corporation}

MR John Davies, Secretary of State for Trade and Industry, hinted in a reply to $\mathrm{Mr}$ Gregor Mackenzie that the government is considering making changes in the structure of the British steel industry. He said that he is engaged in discussions with the British Steel Corporation to try to develop a structure for the industry which will assure it of a prosperous and satisfactory future. He also said that it would not be correct to assume that the management of the industry believes that it should be left exactly as it is. (Oral answers, November 9.)

\section{National Health Service}

SIR KerTH JosePH, Secretary of State for Social Services, gave details of how the government plans to spend the English share of the extra $£ 110$ million which will be made available to the social services over the next four years. A large share of the money will be spent on provision for the mentally handicapped and on improvement of hospital and local authority services for old people and the mentally ill. Each of these services will receive $£ 40$ million from the $£ 110$ million.

The Secretary of State also said that he hopes to make a statement soon about family planning, and about improvements in the accident and emergency services. A revicw of what should be done in these areas, he said, is under way. $£ 3$ million will also be set aside over the next four years for special units for the chronic sick, and an extra $£ 2$ million to improve facilities and advice for alcoholics.

The total resources available for the hospital, local authority and welfare services for 1971-72 will be about £5 million more than during the present financial year. This is an increase of 6 per cent, compared with an increase of $4 \cdot 3$ per cent during 1969-70. (Statement, November 11.) 